\title{
MÕNEST NAHATÖÖTLUST MÄRKIVAST MURDESÕNAST ${ }^{1}$
}

\author{
VILJA OJA
}

\begin{abstract}
Annotatsioon. Eesti kirjakeelne nahatöötlustermin parkima märgib põhjaeesti murretes igasugust toornaha töötlusprotsessi üldiselt. Lõunaeesti murretes tähendab parkima peamiselt toornaha hapendamist puukooreleotises, kuid karusnaha saamiseks pidi nahka pesmä, st jahusegus hapendama. Hiiumaal ei ole kumbki neist verbidest - parkida ega peksta - nahatöötlusterminina murdeomane. Hiiu- ja Muhumaal ning kohati Saaremaal tähistab toornaha parkaines ehk tammes leotamist tamm-tüveline verb. Kasukanaha jaoks aga mäidati toornahka mädis. Artiklis antakse ülevaade nende sõnade kasutusest eesti murretes, esitades võrdlusainest ka kontaktkeeltest. Seejuures analüüsitakse sõnade tähendussuhteid ja päritolu. Võtmesõnad: eesti murded, nahaparkimine, tamm, mädi, mäitama, peksma
\end{abstract}

\section{Sissejuhatuseks}

Kuna tänapäeval kodust nahaparkimist üldiselt ei harrastata, siis alustuseks väga lühike ülevaade vanaaegsest nahatöötlusprotsessist (täpsemalt vt Aamissepp 1920; Nugis 1943; Viikberg 1980; MTÜ Maavillane koduleht). Naha valik ja töötlemise viis olenesid nahakasutuse eesmärgist. Kasukanahaks võeti harilikult lambanahad, harvem muud, nt vasikanahad. Karusnaha saamiseks hapendati toornahku rukki- või kaerajahust valmistatud püdelas segus lühikest aega - eri andmeil ööpäev kuni nädal. Elastseks muutunud nahad kuivatati ja koogitseti (kaabiti nahakooguga puhtaks ja klopiti pehmeks).

Jalanõude ja paljude tarbeesemete jaoks kasutati enim veisenahka. Toorelt loomanahalt irrutati lubja- või tuhaleotises esmalt karvad. Seejärel pandi nahk mitmeks nädalaks või isegi kogu talveks puukooreleotisse hapnema. Murdekogus leiduvate andmete kohaselt on eestlased parkimissegu teinud paju-, kuuse-, pihlaka-, toominga-, tamme-, lepa-, pärna- ning kase-

${ }^{1}$ Uurimistööd on rahastatud projektidest ETF9367 ja SF0050037s10. 
koortest. Parginõus nahku aeg-ajalt liigutati, pöörati, tambiti jms. Lõplik viimistlus toimus olenevalt naha otstarbest. Näiteks tallanahka rasvatati, siluti, siis kuivatati ja pressiti (rulliti). Puukooreleotisega taimparkimist tunti juba Vana-Indias ja -Egiptuses u 3000 aastat e.m.a. Eestis olid taimsed vahendid parkainena levinud veel XX sajandi algul (EE 7: 202).

Eesti kirjakeelsetest terminitest parkima ja park ning murretes laialt tuntud nimetustest peksma ja hapatus jms on artiklis juttu üksnes põgusalt. Põhjalikumalt käsitletakse saarte murdes nahatöötlust väljendavaid sõnu tamm ja tammema ning mädi ja mäitama, mis on tõenäoliselt paljudele eestlastele uudiseks. Analüüsitakse sõnade omavahelisi suhteid ja päritolu. Eesti murdematerjal on saadud eesti murdesõnavara kogust (EMSUKA) ja murdetekstide väljaannetest. Näited esitatakse enamasti lihtsustatud transkriptsioonis, kus III väldet osutab pikkusmärk (graavis) sõna ees ja palatalisatsiooni vastav märk (akuut) konsonandi juures ning lõunaeesti ülipikki kõrgenenud vokaale tähistab erimärk tähe all. Sõnaraamatutest võetud teiste keelte aines esitatakse muutmata kujul.

\section{Nahka parkima ja peksma}

Tööprotsessi, mille tulemusel toornahast saadakse tarbeesemete valmistamiseks sobiv materjal, nimetatakse enamikus põhjaeesti murrakutes nagu kirjakeeleski parkimiseks ja selle töö kutselist tegijat parkaliks, parkmeistriks, parksepaks või parkijaks (EKSS 4: 181; EMSUKA). Näiteks Hää Igaüks isi kõike `nahka ei ’parkinu, ’óllid ’parkijad (MPH: 113); Vil pargitud nahast 'tehti mõlemid, 'paĺlid ('paljaid') ja 'rõ̃̃vaga kasukid (EMM: 91). Samamoodi nagu eesti keeles, kasutatakse soome murretes verbi parkata või parkita, karjala keeles parkita või parkittaa ja vadja keeles parkita (vt nt ALFE 3: 324, 328-330). Kitsamalt, tähenduses 'toornahka parkainega töötlema' esineb park-tüveline verb kõikides läänemeresoome keeltes peale vepsa ja liivi. Murdematerjalis on sageli raske täpselt kindlaks määrata, kumba tähendust on silmas peetud, seepärast pole nende levikualad keeleatlase kaardil teineteisest eristatud (vt ALFE 3: 327). Vanemas lõunaeesti murdes märgib ’paŕkma harilikult protseduuri jalatsite ja tarbeesemete naha valmistamiseks, mitte aga karusnaha saamiseks, nt Rõu [Sepalõõts] oll tett paŕgitust eläjänahast ('veisenahast') (KVVE: 326). Uuemas murdes on see verb levinud üldises (kirjakeelses) tähenduses, nt Rõu Kitsõnahast tet'ti 'kindiid ja kasukiid. Tuu paŕgiti är nigu lambanahk (KVVE: 593). 
Eesti nagu ka soome ja karjala verbide aluseks on noomen park (sm parkki), mida mõlemal pool Soome lahte peetakse rootsi $(<\mathrm{rts}$ bark 'puukoor; park(aine)') laenuks (EES: 354; SKES: 493). Sama tüvega verb väljendab rootsi keeles, sh soomerootsi murretes, mõisteid '(puud) koorima' ja 'parkima (parkainega immutama)': rts bark, barka < germ *barku- (Hellquist 1922: 31; OFSF 1: 123; SAOB: s.v. bark). Julius Mägiste esitas eesti sõna võimaliku allikana küsimärgiga ka alamsaksa sõna bark (EEW: 1940-1941). Alamsaksa sõnaraamatus leidub küll märksõna „bark”, kuid puukoorenimetuse sõnakujuks on märgitud borke (Grimm 2: 243; Schiller-Lübben 1: 397). Vadja murretesse on sõna tõenäoliselt laenatud eesti keele vahendusel ning karjala lüüdi murdesse soome keele kaudu (SSA 2: 316). Kutselise nahaparkija nimetused, eesti parkal ja soome parkkari, on varasemad laenud vanarootsi keelest ( $<$ vrts barkare id.; EES: 354; SSA 2: 316).

Kasukanaha töötlemise kohta öeldi vanemas lõunaeesti murdes ’pesmä 'peksma' ning parkal oli (naha) 'pesjä, nt Krk [tuleks] 'lambanaha är 'pesje kätte viiä; Hel naha 'pesjä, venelise ('venelased') 'pesseve; Nõo vanast, ku 'kaska 'nahku 'pesti, sis 'olli aput 'aisu kõik ilm täis; Ote mud'u ei saa 'nahka kaskass tetä, ku ei pessetä (EMSUKA); Rõu [Kasukanahad] 'laśti naha peśjäl pessä (KVVE: 326). Vahel on sama verbi kasutatud laiemalt, ka karvadeta naha parkimise kohta, nt Rõn nahk 'laśti paŕksepäl ärä 'pessä, sai tśuvvanahass ('pastlanahaks'); Räp Pargite - - 'rahkess härä nahko vägi pestölt 'pargiti rangiroomade jaoks härjanahku rasvaga töödeldult' (KVVE: 225). Võimalik, et varem on 'pesmä lõunaeesti murdes käibinud üldnimetusena tähenduses 'nahka parkima' ning 'paŕkma väljendas pigem mõistet 'peksma, nüpeldama, kolkima'.

Samamoodi nagu lõunaeesti murdes, väljendatakse karusnaha töötlemist liivi ja vepsa keeles: vrd liivi $p^{i} e \overline{k s} e \hat{\text {, }}$ vepsa peksta 'toornahast kasukanahka valmistada' (Kettunen 1938: 299; SVJ: 406). Karjala keeles, päriskarjala ja Aunuse murdes kasutatakse pieks-tüvega verbi (piekšüä, pieksie, pieksta) igasuguse naha kogu töötlusprotsessist rääkides, samuti nagu eesti kirjakeeles kasutatakse sõna parkida (KKS 4: 260-261; Makarov 1990: 264). Verb peksma pärineb uurali tüvest *peksä-, karjala sõna esisilbi diftong -ie- $(<* \bar{e})$ on sekundaarne (EES: 360; EEW: 1982-1983; SKES: 536-537; SSA 2: 349; UEW: 368-369). Enamikus Uurali keeltes esinevad selle vasted tähenduses 'lööma, kloppima'. Mõistet 'nahka parkima' väljendatakse peale eelmainitud läänemeresoome keelte nõnda veel mari, permi ja samojeedi keeltes. 
Karusnaha hapendamiseks tehtud jahusegu nimetati eesti murretes apand, apandis, apandus, apants, (h)apatus, hapendis, hapendus, apetes, hapnik. Näiteks Lüg kus 'lamba nahad sies ôlid, sie õli appatuss, tõist üeldi `rohkemb park (EMS I: 382); Mar naha apendes, 'nahka apendasse seal sees (EMS I: 383); Se naha ’peśmise `haṕnik (EMS I: 385).

\section{Tamm ja tammema}

Hiiumaal tavaliselt ei pargita ega peksta nahka. Hiiu murdest on küll kirja pandud üksikud teated verbi parkima kohta, kuid murdepärane tegusõna on

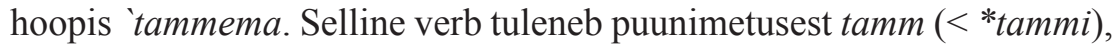
mille koor on teatavasti suure tanniinisisaldusega ning seetõttu väga hea aine nahaparkimissegu valmistamiseks. Julius Mägiste arvates võib eesti verbi tuletusmall olla mõjutatud analoogilisest venekeelsest konstruktsioonist, mis lähtub samuti tammepuu nimetusest ${ }^{2}$, vrd vn дубить 'parkima' < дуб 'tamm' (EEW: 3069-3070). Mandri-Eestis ei ole tamm sage puuliik, kuid kasvab rammusas mullas hästi suureks ning seda võimast puud on lausa pühaks peetud. Läänesaartel kohtab tammi tunduvalt enam kui mujal ning siinsed asukad on neid ka rohkem tarbepuuna kasutanud (vt nt Viires 1975: 105 jj).

Parkainet ja parkimisvedelikku märgib nimisõna tamm Hiiumaal, Lääne-Saaremaal ja Muhus, nt Khk tamm ‘ömbas tä (naha) punaseks ning kövamaks `jälle; Pöi tamm tegi naha ‘sitkeks ja `pehmeks. Sõna muutevormides on tüvevokaaliks - $e$ (Jäm Muh Emm Rei Phl), -i (Khk Kaa Mus) või - $a$ (Käi Phl). Näiteks Rei nahad 'panta sügise ‘tamme, kevade vööda `välja; Phl tammetörs; Khk nahad on `tammis; Kaa katsuti tammi kangust; Käi [Kuus nädalat hoiti] 'tammas; Phl tamma tünn; [Poisid käisid tõrres] 'tamma `sötkumas. Tammepuu nimetus on obliikvakäänetes $e$-tüveline. Kuidas siis seletada $i$ - ja $a$-lõpulisi parginimetusi? Kui nahaparkimiseks kogutud puukoori ja neist valmistatud parkimissegu tähistav noomen tuleb puunimetusest, võivad $i$ - ja $a$-lõpulised vormid lähtuda mitmuse tüvest. Sisuliselt saab seda põhjendada nii, et parkaine allikast, purustatud puukoortest räägitakse mitmuse vormis ning selle järgi

$2 \operatorname{Vrd}$ vn $\partial y \sigma,-a$ ja $-y$. m. 'mõnede puuliikide (tamme, kase, paju jt) koor, mida kasutatakse nahaparkimiseks, aga ka millegi värvimiseks'; $\partial у б a,-b l$. f. 'pajukoor, mida kasutatakse naha parkimiseks', nt Leningrad: А мама дубу драть ушёдии.; Aunuse murdes Karjala alal: песню пели пока не стали дубу драть (SRNG: 231, 232). 
nimetatakse mitmuslikuna ka pargisegu. Näiteks Hiiumaal Reigi murrakus on pargisegust jutustades kasutatud ka de-mitmust: nahad toodagse är, ’pantakse ‘tamme. - - toodagse kaeust vett ja ’pantags jälle 'nahkade ’pääle, ‘tammede 'pääle. - -kaks kolm kuud on, siis akedags `vaatama, et kas siis nahad on 'apnemas ja kas sis nahad on 'tammes ka (SMT: 540). Teiselt poolt on arvatud, et sõnakuju tamme- tuleneb algläänemeresoome $a$-tüvelisest noomenist $<$ ? *tom(m) a (Itkonen 1977: 5, 11-12).

Samal alal on levinud ka $e$-, $i$ - ja $a$-tüvega verbid: $\mathrm{t}$ a $\mathrm{m}$ m e $\mathrm{m}$ a (või tammetama), nt Muh nee nahad o sandist ('kehvasti') tammetot; Emm Nahku tammema; t a m m i m a (või tammitama), nt Khk puu koordega tammidase; Mus ma pole kuuland, et pares cnam `keskid kodu tammidaks; t a m m a m a, nt Phl 'Nahka 'tammama; tammadi elutoas. Noomeni ja verbi ühendit, nagu tammes olema, tamme sisse (või 'tamme) panema, kasutatakse võrdväärsena tamm-sõnast tuletatud verbiga ( 'tammema jt). Mõnikord vahelduvad need ühes tekstis, nt Khk nahad on 'tammis, `nahku tammitasse; Muh veisse nahk tammetati ää, pandi tamme `sisse; Emm Peaks nahad 'tamme panema, Jüril juba tammet.

Ehkki tamme nimetusest moodustatud sõna viitab sellele, nagu oleks parkaine allikaks tammekoor, on parkimissegu sageli valmistatud hoopis paju, pihlaka või mõne muu puu koorest, nt Khk paneb paeu koordega 'tamme; Pöi Paju kordega tammetati ää, 'liutati paar kuud paju korde vee sihes. Sama verb, tammema vms, võib märkida nii karusnaha kui ka karvadeta (jalatsite, sepalõõtsa $\mathrm{jm}$ ) naha töötlust, nt Jäm vana tammet pelts ('poolkasukas') oli seljas; Muh vassika nahad tammetatse tamme koordega ää, ühna punaseks 'lähtvad; tammetet ( tammet) 'nahka 'paslid; Phl tammedod nahast `saapad. Ferdinand Johann Wiedemanni sõnaraamatus (1973: 1116-1117) on registreeritud tamm tähenduses 'parkaine, puukoortest parkimissegu' koos näitefraasiga ,paju-okse tamme-kooreks tooma" ning verbid tammema, tammetama seletusega 'parki panema' ja tammima 'parkima (koorepargis)'.

Eesti läänepiiril pole parki ja parkimist väljendavad sõnad siiski unikaalsed. Analoogilised nahatöötlusterminid, mis lähtuvad tamme nimetusest, esinevad liivi keeles. Tammepuu on liivi keeles täm, g sg tām, pl liI tōmâ $D^{3}$, liL tǟmồ. Parkainet ja puukoortest valmistatud parkimis-

3 Vokaal $\ddot{a}$ nimetavas ja $a$ omastavas käändes osutab sõna varasemale kujule: *tammi : *tammõ-. Idaliivi mitmuse vormis toomõd $(<*$ tammõt) on toimunud reeglipärane häälikumuutus, kus helilise geminaatkonsonandi ees olev $a>a a>o o$ (vt Kettunen 
vedelikku nimetatakse tamm ja tōma, pl tōmad (Sjögren 1861: 111, 115, 230). Sellest on moodustatud pargianumaid märkivad liitsõnad tōma-bōl'a ja tōma-mol'd , nt tōma-bōl'as .. tōmińt't'ist nō'gidi 'pargianumas tammiti nahku'. Nahaparkimise jaoks varutud paju- ja kuusekoori nimetati tōma kùorâD 'pargi koored', nt tōma kùorât saìttâ kùoŕštàt alabôst un paistâ un $k \bar{u} z \hat{s} s t$ 'pargi koored sai kooritud halapajust ${ }^{4}$ ja pajust ja kuusest' (Kettunen 1938: 430). Liivi laused panàb_nō'gât_tammô (Kettunen 1938: 408) ja panàb_nō'gâ tà̀mâz (Kettunen 1938: 430) vastavad struktuurilt ja sisult täpselt eesti saartemurdelisele: paneb naha(d) tamme. Eesti verbi tammida vastena annab liivi sõnaraamat tōmaťtâ ja tōmińt't' $\hat{\partial}, \mathrm{pr}-b, \mathrm{nt} n \bar{o}$ 'gât sōbôt tōmińt't'àt 'nahad saavad pargitud' (Kettunen 1938: 343, 430).

\section{Mädi, mädima ja mäitama}

Nimisõna mädi esineb saarte murdes ning selle naabruses Hanila ja Karuse murrakus tähendustes 'märg mass, pori; sodi, mustus; oksarisu; viljapraht (tuulamisel)'. Kitsamas mõistes märgib mädi püdelat (jahu)segu naha parkimiseks, nt Pöi pani nahad mädise; Muh kui `lamba nahad mädis oo. Puukoortega parkides värvub nahk (punakas- või kollakas-) pruuniks. Kui taheti valget nahka, kasutati parkimisel mädi. Pealegi sai mädi abil teha kvaliteetsema karusnaha.

Mädi koostist on Jämaja murrakus kirjeldatud nii: 'vööti kaks 'naela rugi jahu ning poolteist `naela `soola vana Yamba naha ’pecle ning ’tehti sedine mädi. Värskelt segatud mädi ei sobi parkimiseks. Muhus õpetati nõnda: kahessa ’äeva enne mädi seisab nõu sees, et ta ea apu oo. Hanila keelejuht selgitab, kuidas mädi mõjub: Mädi sihes lasti kasukanahad apneda, siis läksid nad koogitsedes pehmes. Hapendusseguga nõu on Hiiumaal nimetatud mädipütt, Karuse murrakus mäditoor (toor 'toober'). Parkali kohta on öeldud Mustjalas 'nahka vaander ehk va mädi 'mihkel, kes 'nahka mädiks teeb. Viimases lauses esineb ühtlasi noomen mädi adjektiivses tähenduses 'pehme, painduv' vms (EMSUKA).

1960: 127-131). Erkki Itkonen (1977: 5, 11-12) aga oletas esisilbis algupärast $o$-d: tamm $<$ ? *tom (m)a; pl *tammii- <*tommei- ja *toomii- <*tomei-.

4 Võib-olla räägitakse hanepaju ja liivpaju või ka hundipaju hübriidist (Salix repens, phylicifolia või pentandra) (SSA 1: 132). Kuramaa liivased rannaalad peaksid liivpaju hübriididele olema soodsam kasvukoht kui halapajudele (vt nt TVM: 350). 
Denominaalne verb mädima märgib saarte murdes peamiselt hautades pehmenemist või ligunemist, nt Muh õunad pani mädima [kerisele]; lapsed soavad karjas mädida [vihma käes]; ma pane tubaka mädima; lase pudrul veel natuke mädida; tael 'pandi kirisele mädima, vee 'sisse, et ta 'easte 'pehmeks läks; ta (tael) mädis palava vee sees, ta pole keen mette. Naha „mädimisest” räägitakse Mustjala murraku näites: mädis va lubjaste tooreste nahkadega, mida võib mitmeti tõlgendada - seda verbi kasutatakse ka tähenduses 'määrima, mätserdama'. Teise sama tüvega verbi mädistama (nt Kse `nahkur mädistab `nahka) tähenduseks on koguja märkinud 'parkima' (EMSUKA).

Kausatiivses tähenduses 'pehmitama, leotama; nahku jahusegus hautama' ning 'võidma, määrima' esineb tavaliselt verb ‘mäitama (Jäm Khk Muh) või ‘mäidama: 'mäid-, 'mäit- (Hi). Näiteks Khk akkame `nahku 'mäitama, 'nahku mädisse panema; Muh mädiga 'mäitatse 'nahku; ma ole ise 'mäitan koa, jahudega 'mäitasse; Rei Nüüd pole ulgal ajal änam 'nahku kodu 'mäidat; Phl 'lamba `nahku mäidadi mädi tooris. Siiski pole verbikasutus piirdunud üksnes kasukanahkade hapendamisega jahusegus, vaid mõnikord on nõnda nimetatud ka karvadeta naha töötlemist. Näiteks Muh lõhmuspuu koordega `mäitasse 'nahku; kui nahad ää 'mäitatse, siis kile kord peal o naha ind; Rei Kinyaröhmad tehti vanal ajal vinnat voi mäidat nahast (EMSUKA).

F. J. Wiedemanni sõnaraamatus esineb noomen kujul mädi, g mädi, mäe 'meski; segu valgeks parkimiseks, parkaine', mädi-nahk 'valge pargitud nahk' ning Hiiumaalt verb mäitama 'valget nahka parkima; tubakat parkima' (Wiedemann 1973: 583-584). Varasemad õigekeelsussõnaraamatud annavad noomeni mädi, g mädi 'soga, löga' ja sellest tuletatud adjektiivi mädine märgendiga „murdeline” (nt ÕS 1976: 440). Uuemates kirjakeele sõnaraamatutes (sh EKSS) seda sõna ei mainita.

J. Mägiste on eesti sõna mädi seostanud deskriptiivse verbiga mätsima ning soome sõnadega mäsä, mäsy (EEW: 1609, 1624). Eesti murdesõna mädi täpne häälikuline vaste soome keeles oleks Lääne- ja Põhja-Soome murretes kalamarja (või -niiska) tähistav noomen mäti. Nii eesti mädi kui ka soome mäti on levinud keeleala läänepoolses osas. Tähenduselt ei jää need teineteisest samuti kaugele - mõlemad tähistavad mingit pehmet ollust või pudrutaolist massi. Soome mäti on päritolult ühendatud sõnaperega mähnä (? eesti mõhn) (SSA 2: 194; SKES 360). Ka „Läänemeresoome keeleatlases" kalamarjanimetuste kaardil on märksõna mäti alla 
koondatud ühtlasi soome kalamarjanimetused määhnä, mähnä, karjala mähnä, mähändä, mädähn, mädähmö ning põhjavepsa mädahm (ALFE 3: 245-246). On muidugi võimalik, et soome mäti, mähnä, mädähn jms lähtuvad ühest juurest, ehkki välistada ei saa ka teistsugust lahendust, ent seda oskavad soome keele asjatundjad täpsemini otsustada. Eesti sõna mädi saab häälikuliselt ja tähenduse poolest seostada saartemurdelise verbiga mäitama. Mõlemal sõnal on lähedased vasted rootsi keeles, vrd rts smet 'määre, sodi' ja 'taigen', smeta 'määrima', 'võõpama', smetig 'must, määrdunud' (RES: 334). Nii nagu meie saarte murdes, on soome keeles Länsipohja murdealal ja Peräpohjala lääneosas kasutatud sõnu meitto 'jahusegu naha parkimiseks' (nt Täräntö ensin om piettü nahka meitossa 'esmalt on hoitud nahka jahusegus haudumas'), meitota 'hautada, valgena parkida', meittoaminen jms (SMSA). Etümoloogiasõnaraamatute kohaselt on soome sõnad laenatud vanarootsi või rootsi keelest, vrd vrts smêta (< germ *smeitan), rts smeta, murd smeita jm, sm-rts smeta, smäit 'määrida, võida; värvida' ja smet, smeta 'puderjas mass, löga, jahukört, tainas' ning eraldi laenuna rootsi keelest on siinjuures mainitud eesti saarte murde verbi mäidata (EEW: 1613; SAOB: s.v. smet; SSA 2: 139, 157; SKES: 464).

Saksa keeles esinevad samatüvelised sõnad lühikese vokaaliga, märkides muu hulgas tähendusi 'puder v kliister kanga ja lõime tugevdamiseks' ja 'kleepuva kliistriga immutama': Schmitze, schmitzen < (k)asks smette, smitte, smetten, smitten (Grimm: 15, 1104; Gutzeit: 144-145; Schiller, Lübben: 4, 265). Tänapäeva eesti kirjakeeles tuntakse alamsaksa laenudena termineid mett 'kleepuv vedelik lõimelõngade immutamiseks' ja mettima 'lõnga metiga immutama' (EEW: 281; EKSS 3: 416; ÕS 2013: 540). Murretes on linaseemneõlist tehtud kangamääret nimetatud mett (Koe) ja sellega töötlemist mettima (Tor Plt KJn, 'met'mä Kod) või mitt (mit't) ja mittima (Vig Aud, 'mit'mä eL). Saare- ja Muhumaal ning naabruses (Var) on verbi mättima (Han mettima) kasutatud üldisemas tähenduses 'määrima' (näiteks määrima saviga, poriga, toiduga, kritseldustega vm), lisaks on Muhust kirja pandud verb metitama 'immutama'. Noomeni kohta on saarte murdest vaid paar teadet: Jäm mett, g meti 'rukkijahust nõrk kliister', Muh mitt, g miti 'jahu-pärmi segu' (EMSUKA). Tõenäoliselt pärineb saarte murde mädi eelkäsitletutega samast juurest, ent täpsem etümoloogia on ebaselge. 


\section{Kokkuvõte}

Enamikus põhjaeesti murretes väljendab verb parkima nii nahkade hapendamist parginõus kui ka toornaha kogu töötlusprotsessi. Vanemas lõunaeesti murdes märgib ’parkma üksnes jalatsite jt tarbeesemete jaoks naha töötlemist puukoorepargiga. Nagu põhjaeesti murdes nii kasutatakse park-tüvelist verbi laias tähenduses ka soome, karjala ja vadja murretes. Kitsamalt, tähenduses 'toornahka parkainega töötlema' esineb park-tüveline verb kõigis läänemeresoome keeltes peale vepsa ja liivi. Karusnaha valmistamise protseduuri, kus toornahka jahusegus hapendatakse, nimetatakse lõunaeesti murdes 'pesmä. Võimalik, et varem on see sõna siin käibinud üldisemalt tähenduses 'nahka parkima'. Samamoodi nagu lõunaeesti murdes, väljendab peks-tüveline verb karusnaha töötlemist liivi ja vepsa keeles. Karjala murretes kasutatakse pieks-tüvega verbi tähenduses 'parkima' igasuguse naha kogu töötlusprotsessist rääkides.

Hiiumaal, Lääne-Saaremaal ja Muhus märgib parkainet ja parkimisvedelikku tamm (g -e, $-i$ või $-a$ ) ning nahatöötlust sama tüvega verb. Selle aluseks peetakse tammepuu nimetust. Parki ja parkimist väljendavad $i$-ja $a$-tüvelised sõnad võivad lähtuda mitmuse vormist. Teiselt poolt võib tüvevokaali varieerumine kajastada varasemat sõnakuju. Analoogilised tamme nimetusest tulnud sõnad esinevad liivi keeles. Karusnaha parkimist tähistab Hiiu- ja Muhumaal ning Lääne-Saaremaal verb 'mäitama, 'mäidama ning selleks tarvitatavat püdelat jahusegu nimetatakse saarte murdes mädi. Sõnad mädi ja 'mäitama, ’mäidama võiksid pärineda ühisest algtüvest, vrd rts smet, smeta (murd smeita, smäito jt), kasks smette, smitte, smetten, smitten.

\section{Kirjandus}

Aamisepp, Julius 1920. Kodune nahaparkimine. Wiljandi: H. Leokese raamatukauplus.

ALFE $=$ Atlas Linguarum Fennicarum. ALFE 3. 2010. Itämerensuomalainen kielikartasto. Läänemeresoome keeleatlas. Ostseefinnischer Sprachatlas. Лингвистический атлас прибалтийско-финских языков. Päätoim. Tuomo Tuomi. 3. osan vastaava toimittaja Vladimir Rjagoev. Toimitus: Anneli Hänninen, Raimo Jussila, Helmi Neetar, Vilja Oja, Seppo Suhonen, Tiit-Rein Viitso, Nina Zaitseva. Kartat: Anneli Hänninen; saksankielinen käännös: Klaas Ph. Ruppel, venäjänkielinen käännös: Vladimir Rjagojev, Nina Zaitseva, vironkielinen käännös: Helmi Neetar 
(= Suomalaisen Kirjallisuuden Seuran Toimituksia 1295, Kotimaisten kielten tutkimuskeskuksen julkaisuja 159.) Helsinki: Suomalaisen Kirjallisuuden Seura, Kotimaisten kielten tutkimuskeskus.

$\mathbf{E E}=$ Eesti Entsüklopeedia. 7, 1994. Tallinn: Eesti Entsüklopeediakirjastus.

EES = Iris Metsmägi, Meeli Sedrik, Sven-Erik Soosaar 2012. Eesti etümoloogiasõnaraamat. Eesti Keele Instituut. Tallinn: Eesti Keele Sihtasutus.

EEW = Julius Mägiste 1982-1983. Estnisches etymologisches Wörterbuch. I-XII. Helsinki: Finnisch-Ugrische Gesellschaft.

EKSS = Eesti keele seletav sõnaraamat. 1-6, 2009. „Eesti kirjakeele seletussõnaraamatu" 2., täiendatud ja parandatud trükk. Toim. Margit Langemets, Mai Tiits, Tiia Valdre, Leidi Veskis, Ülle Viks, Piret Voll. Eesti Keele Instituut. Tallinn: Eesti Keele Sihtasutus.

EMM = Ennemustitsel Mulgimaal. 2008. Toim. Helju Kaal, Mari Must, Eevi Ross. (= Valimik korrespondentide murdetekste VII.) Eesti Teaduste Akadeemia Emakeele Selts. Tallinn: Emakeele Selts.

EMS = Eesti murrete sõnaraamat. I (A-J), 1994-1997. Koost. Anu Haak, Evi Juhkam, Mari Must, Mart Mäger, Helmi Neetar, Salme Nigol, Ellen Niit, Vilja Oja, Valdek Pall, Eevi Ross, Aili Univere, Helmi Viires. Käsikirja ühtlustanud ja täiendanud Mari Must. Trükki toimetanud Helmi Neetar, Ellen Niit, Eevi Ross. Eesti Teaduste Akadeemia Eesti Keele Instituut. Tallinn: Eesti Keele Instituut.

ERL $=$ Gea Troska, Ants Viires, Ellen Karu, Lauri Vahtre, Igor Tõnurist 2000. Eesti rahvakultuuri leksikon. 2., täiendatud ja parandatud trükk. Koost. ja toim. Ants Viires. Tallinn: Eesti Entsüklopeediakirjastus.

Gutzeit $=$ Woldemar von Gutzeit 1898. Wörterschatz der deutschen Sprache Livlands. Nachträge zu A-V. Riga: In Commission bei N. Kymmel.

Hellquist, Elof 1922. Svensk etymologisk ordbok. Lund: C. W. K. Gleerups Förlag.

Itkonen, Erkki 1977. Die Umwandlung einiger $a$ - und $\ddot{a}$-Stämme zu $e$-Stämmen in Urfinnischen. - Suomalais-Ugrilaisen Seuran Aikakauskirja 75, 5-30.

Kettunen, Lauri 1938. Livisches Wörterbuch mit grammatischer Einleitung. (=Lexica Societatis Fenno-Ugricae V). Helsinki: Suomalais-Ugrilainen Seura.

Kettunen, Lauri 1960. Itämerensuomalaisten kielten luonteenomaiset piirteet. (= Suomalais-Ugrilaisen Seuran Toimituksia 119.) Helsinki: SuomalaisUgrilainen Seura.

KKS $=$ Karjalan kielen sanakirja. 4, 1993. (= Lexica Societatis Fenno-Ugricae XVI, Kotimaisten kielten tutkimuskeskuksen julkaisuja 25.) Helsinki: Suomalais-Ugrilainen Seura.

KVVE = Kuiss vanal Võromaal eleti. 2005. Toim. Helju Kaal, Mari Must, Eevi Ross. (= Valimik korrespondentide murdetekste VI.) Eesti Teaduste Akadeemia Emakeele Selts. Tallinn: Emakeele Selts. 
Makarov $1990=$ Г. Н. Макаров. Словарь карельского языка (Ливвиковский диалект). Карельский научный центр Академии наук СССР. Институт языка, литературы и истории. Петрозаводск: Карелия.

Nugis, Elmar 1943. Tähtsamate nahaliikide kodune parkimine: pastlanaha parkimine, kasukanaha parkimine, raagnaha parkimine. Tallinn: Agronoom.

MPH = Minevikupärandit Häädemeestelt. 2012. Kogunud Marta Mäesalu. Koost. ja toim. Helju Kaal, Evi Ross. (= Valimik korrespondentide murdetekste VIII.) Tallinn: Eesti Teaduste Akadeemia Emakeele Selts.

OFSF $=$ Ordbok över Finlands svenska folkmål. I (A-E), 1982. Red. Olav Ahlbäck. (= Forskningscentralen för de inhemska språken. Skrifter 1.) Helsingfors: Svenska litteratursällskapet i Finland.

RES $=$ Rootsi-eesti sõnaraamat. 1979. Koost. Ülev Aaloe, Ilmar Mullamaa, Tiina Mullamaa, Anu Saluäär, Juhan Tuldava, Enno Turkmen. Toim. Henrik Sepamaa. Tallinn: Valgus.

Saareste, Albert 1924. Leksikaalseist vahekordadest eesti murretes. I. Analüüs 60 kaardi ja 1 skeemiga. Résumé: Du sectionnement lexicologique dans les patois estoniens. I. Analyse avec 60 cartes et 1 esquisse schématique (= Acta et Commentationes Universitatis Dorpatensis. B VI, 1.) Tartu.

Schiller, Lübben $=$ Karl Schiller, August Lübben 1877-1917. Mittelniederdeutsches Wörterbuch. I-IV. M. Bremen: J. Kühtmann.

Sjögren, Andreas Johan 1861. Livisches-deutsches und deutsches-livisches Wörterbuch. Im Auftrage der Kaiserlichen Akademie der Wissenschaften, bearbeitet von Ferdinand Joh. Wiedemann. St Petersburg: Kaiserliche Akademie der Wissenschaften.

SKES = Erkki Itkonen, Yrjö H. Toivonen, Aulis J. Joki 1955-1981. Suomen kielen etymologinen sanakirja. I-VII. (= Lexica Societatis Fenno-Ugricae XII, 2. Tutkimuslaitos „Suomen Suvun” julkaisuja III). Helsinki: SuomalaisUgrilainen Seura.

SMS $=$ Suomen murteiden sanakirja. 4, 1994. 6, 1999. (= Kotimaisten kielten tutkimuskeskuksen julkaisuja 36.) Helsinki: Kotimaisten kielten tutkimuskeskus, Painatuskeskus/Edita.

$\mathbf{S R N G}=$ Словарь русских народных говоров. 8, 1972. Академия наук СССР. Институт русского языка, словарьный сектор. Ленинград: Наука.

SSA = Suomen sanojen alkuperä. Etymologinen sanakirja. 1-3, 1992-2000. Päätoim. Erkki Itkonen, Ulla-Maija Kulonen. (= Suomalaisen Kirjallisuuden Seuran toimituksia 556, Kotimaisten kielten tutkimuskeskuksen julkaisuja 62.) Helsinki: Suomalaisen Kirjallisuuden Seura, Kotimaisten kielten tutkimuskeskus.

SVJ = М. И. Зайцева; М. И. Муллонен 1972. Словарь вепсского языка. Академия наук СССР. Карельский филиал. Институт языка, литературы и истории. Ленинград: Наука. 
TVM = Maret Kask, Vilma Kuusk, Liivia Laasimer, Aino Mäemets, HaideEne Rebassoo, Silvia Talts, Linda Viljasoo 1972. Taimede välimääraja. Käsiraamat kõrgemate taimede tundmaõppimiseks. Koost. Vilma Kuusk. Tallinn: Valgus.

UEW = Karoly Rédey 1986-1988. Uralisches etymologisches Wörterbuch. Unter Mitarbeit von Marianne Bakró-Nagy, Sándor Csúcs, István Erdélyi, László Honti, Éva Korenchy, Éva K. Sal und Edit Vértes. Wiesbaden: Harrassowitz.

Viikberg, Jüri 1980. Nahaparkimine. - Kodumurre 14. Toim. Heino Ahven. Tallinn: Eesti NSV Teaduste Akadeemia Emakeele Selts, 63-67.

Viires, Ants 1975. Puud ja inimesed. Puude osast eesti rahvakultuuris. Tallinn: Valgus.

VMS = Väike murdesõnastik. II, 1989. Eesti NSV Teaduste Akadeemia. Keele ja Kirjanduse Instituut. Toim. Valdek Pall. Koost. Anu Haak, Evi Juhkam, Marja Kallasmaa, Ann Kask, Ellen Niit, Piret Norvik, Vilja Oja, Aldi Sepp, Jaak Simm, Jüri Viikberg. Tallinn: Valgus.

Wiedemann, Ferdinand Johann 1973 (1893). Eesti-saksa sõnaraamat. EstnischDeutsches Wörterbuch. Neljas, muutmata trükk teisest, Jakob Hurda redigeeritud väljaandest. Tallinn: Valgus.

ÕS 1976 = Õigekeelsussõnaraamat. Toim. R. Kull, E. Raiet. Tallinn: Valgus.

ÕS 2013 = Eesti õigekeelsussõnaraamat ÕS 2013. Toim. Maire Raadik. Koost.

Tiiu Erelt, Tiina Leemets, Sirje Mäearu, Maire Raadik. Tallinn: Eesti Keele Sihtasutus.

\section{Elektroonilised allikad}

Grimm = Jacob Grimm, Wilhelm Grimm 1854-1960. Das deutsches Wörterbuch von Jacob und Wilhelm Grimm. Leipzig: S. Hirzel, auf CD-ROM und im Internet. Ein Projekt des Kompetenzzentrums für elektronische Erschließungs- und Publikationsverfahren in den Geisteswissenschaften an der Universität Trier in Verbindung mit der Berlin-Brandenburgischen Akademie der Wissenschaften Berlin. http://woerterbuchnetz.de/DWB/.

MTÜ Maavillane koduleht. http://www.maavillane.ee/?57.

SAOB $=$ Svenska Akademien Ordbok. http://g3.spraakdata.gu.se/saob/.

\section{Sõnavarakogud}

EMSUKA = Eesti murrete ja soome-ugri keelte arhiiv Tallinnas Eesti Keele Instituudis.

SMSA $=$ Soome murrete sõnaarhiiv Helsingis Kodumaa Keelte Keskuses. 


\title{
On some dialect words related to hide processing
}

\author{
Vilja Oja
}

In North Estonian dialects the verb parkima covers the whole process of hide processing. In South Estonian dialects parkma refers to a procedure where hides were tanned with bark to get leather for footwear and other commodities, whereas for furs the pelts had to be fermented using flour and water, the respective verb being pesmä. It is possible that earlier the verb pesmä was used in South Estonian dialects in a general sense of 'tan hides'. The wide sense applies to the park-stem in Finnish, Karelian and Votic dialects. The narrower sense 'treat hides with a tanning substance' is conveyed by a verb with the stem park- in all Finnic languages except Veps and Livonian, where fur processing is referred to by a verb with the stem peks- as in South Estonian.

In the insular dialect (Hiiumaa, Western Saaremaa, Muhu), the leather tanning substance and fluid are called tamm, with the stem vowel $-e,-i$ or $-a$ (< 'oak'), while the verb describing the treatment is formed from the same stem. Analogous words occur in Livonian. Fur processing is referred to by the verb mäitamal mäidama in these island subdialects and the necessary flour mixture is called mädi. The verb mäitama/mäidama is probably a Swedish loan, cf. Sw. smeta. The etymology of the noun mädi is not entirely clear.

Keywords: Estonian dialects, tanning, tamm, mädi, mäitama, peksma

Vilja Oja

keeleajaloo ja -teaduse osakond

Eesti Keele Instituut

Roosikrantsi 6

10119 Tallinn

Vilja.Oja@eki.ee 